\title{
The Study of Dynamic of Coastal Resource Community-Based Management in Wabula Village of Buton Regency
}

\author{
La Nalefo ${ }^{1}$, Bahtiar ${ }^{2} \&$ Salahuddin ${ }^{1}$ \\ ${ }^{1}$ Department of Agriculture Economic, Faculty of Agriculture, Universitas Halu Oleo, Kendari, Southeast \\ Sulawesi, Indonesia \\ ${ }^{2}$ Department of Sociology, Faculty of Sociology, Universitas Halu Oleo, Kendari, Southeast Sulawesi, Indonesia \\ Correspondence: La Nalefo, Department of Agriculture Economic, Faculty of Agriculture, Universitas Halu Oleo, \\ Kendari 93121, Southeast Sulawesi, Indonesia. E-mail: lanalefo@rocketmail.com
}

Received: July 30, 2018

doi:10.5539/jsd.v11n6p142
Accepted: September 14, $2018 \quad$ Online Published: November 29, 2018

URL: https://doi.org/10.5539/jsd.v11n6p142

\begin{abstract}
Lesson learned on some of traditionally marine resource management had proven that full involvement and authority of traditional institutions are the key to optimum management and sustainability of the agreeable resources, despite the fact that the marine resources is an open access. On the other hand, national government initiative of more centralistic management regime and omitting the role of long existing traditional institutions had not been successful in sustaining the resources. Therefore, this research aims at finding a more adaptive and accommodative community-based maritime resource management, through qualitative approach by description 1) the dynamic of coastal management's implementation on coastal community, 2) the execution of basic principal of coastal management-based on community, on program, and on combinations of community-based and program-based; and 3) key factors in contributing the existence of community-based and program-based coastal management.

Result show that coastal community-based management is constructed and development through continuing socio-cultural changes over time. On the other hand, the dynamic of coastal program-based management is more on the level of community's need and sustainability of the ecosystem. Result also show that the execution of basic principal on coastal management by community is more dynamic and set up locality. The key factors influencing the existence of coastal management are based on the level of community's authority, as well as level of community's participation in management process. Based on the finding, this research recommended an adaptive and accommodative coastal resource management by acknowledging the coastal community capacity supported by the access and control of the government.
\end{abstract}

Keywords: dynamic, coastal resources, fishermen society

\section{Preliminary}

Coastal is a unique area in the context of landscape, the region is the meeting place of land and sea (Key and Alder, 2005, Elmer M. Ferrer and Cristi Marie C. Nozawa 2016; M. Gleason, 2018). The first comprehensive tool kit for coastal planners and those aiming to achieve effective coastal management worldwide. Coastal Planning and Management provides a link between planning and management tools and thus includes all stages in the process, from development through evaluation to implementation (CEA, 2018).

Drawing on examples of successful coastal planning and management from around the world, the authors provide clear and practical guidelines for the people who make daily decisions about the world's coastlines.

Coastal Planning and Management is an invaluable resource for professionals in environmental and planning consultancies, international organizations and governmental departments, as well as for academics and researchers in the local and international fields of geography, marine and environmental science, marine and coastal engineering and marine policy and planning.

Coastal areas are an important area in terms of planning and management points of view. Viewed from its potential, it is divided into four categories, namely (1) renewable resources, such as fish, shrimp and so on, coastal and marine aquaculture activities, (2) non-renewable resources, such as petroleum and gas, (3) marine 
energy, such as tides and waves, (4) environmental services, such as tourism and marine transportation.

Nevertheless the reality of some serious issues has also become strategic issues in the management of coastal and marine resources such as the condition of coastal resources and sea that are common property with access that is quasi open access, more lead to understanding the nature of resources that are public domain and no owner. This condition produces a phenomenon called the dissipatet resource rent, ie loss of borrowing of resources that should be obtained from optimal managemen (Issac Boateng, 2018). With quasi open access then the actions of one party that harms the other can not be corrected by the market (market failure). This creates economic inefficiency because all parties will try to exploit the resources as much as possible, otherwise the other party will get benefit. Reinforced with technology, capitalists are able to excessively exploit resources resulting in the law of the jungle (who is strong, he wins) and the natural production power becomes disrupted.

\section{Focus and Research Question}

This study focuses on the basic principles of ideal CBRM as required by Gruber (2010), such as (1) mobilization and community participation, (2) social capital and partnerships, (3) resources and justice, (4) dissemination of information and communication, (5) research and development, (6) empowerment and delegation of authority, (7) legitimacy and community trust, (8) monitoring, feedback and accountability; (9) collaboration management and adaptive leadership; (10) participation in making decisions, (11) the possibility of the environment optimizing the initial conditions, and (12) cooperation and conflict resolution.

Thus from the identification of the problem described earlier, then the problem formulation in a number of questions as follows:

1) How is the dynamics of coastal resource management implementation in the community?

2) How to apply basic principles of traditional coastal resource management, programs and combination of both?

3) What are the key factors affecting the existence of traditional coastal resource-based management systems with program-based

4) How should the coastal resource management system be applicable or accommodative to the community.

\section{Research Method}

\subsection{Research Site}

The determination of location of the research was carried out purposively in the village units in accordance with the objectives of the study, in order to obtain in-depth data and information about the coastal community in relation to resource management both traditionally and through program intervention. For this reason, the chosen location was Wabula Village, Wabula District, Buton. The selection of the region based on the consideration of the characteristics of the Wabula Village. The village implements a combination of tradition-based coastal resource management systems through Parabela institutions and the Coremap program from the Ministry of Fisheries and Maritime Affairs has been placed.

\subsection{Data Source}

The data obtained from this study are sourced from primary and secondary data (Dagmar Hedrich, et all, 2008., Stephanie Zaza, et all 2000). Primary data was obtained from the results of interviews and direct observation of researchers in the field with informants, namely: Parabela, Imam, Moji, Village Heads, Religious Figures, Community leaders, Fishermen, Collectors, Cultural observer, Lecturers, Non-Governmental Organizations, Government, Facilitators who had working on Coremap, and others. Secondary data comes from relevant agencies, namely the Department of Marine and Fisheries, Buton District.

Qualitative data collection is done through the determination of informants based on initial information about community members involved in resource utilization and management, including fishermen. The next informant uses snowball technique (snowball effect). In addition, there are informants who are self-determined by researchers such as community leaders, traditional leaders, religious leaders, youth leaders, government staff from relevant institutions, and so on.

\subsection{Procedure for Data Retrieval}

In this study, a number of certain effective data are collected and integrated in the analysis process, and are presented in such a way as to support the main themes that are the focus of the research, so that it is a separate construction as a product of interaction between field informants and researchers (Alfgeir Logi Kristjansson, et all 2017). The data collection techniques used include: 


\subsubsection{In-depth Interviews}

In-depth interviews were conducted through a number of meetings with informants in which questions and answers were held and the discussion was involved about various aspects of the problem sought in the study (Adams, et al, 2008; Allmark, PJ, et all, 2009; Crosman, A, 2017; Legard, R., 2003 and Kvale, S. (1996).). Conducting in-depth interviews using internal resources is (1) developing a sampling strategy, (2) writing an in-depth interview guide, (3) conducting interviews and analyzing in-depth interviews (Boyce, C, 2006).

\subsubsection{Observation}

Observations were carried out in two ways, namely ordinary observation and participation. Data collected through observation is data observed by researchers without demanding direct involvement. Participation observations (Dana Lynn Driscoll, 2017), full observation participation were conducted to obtain data that demanded the involvement of researchers in the settings studied, such as the behavior and activities of informants, local institutions and matters relating to the substance of the research problems. Marshal (1995), through observation, researcher learn about behavior, and the meaning of the behavior. Susat Stainbback (1988; Creswell, John, 2004; Crossman, A. 2017 states participatory observation, researchers observe what people do, listen to what they say, and participate in their activities.

\subsubsection{Group Discussion}

Group discussions were conducted with a number of experts through the word cafe format. The implementation through word café format was carried out based on the consideration that in this study consisted of five materials that would be the subject of discussion in each group, namely social, economic, ecological, cultural and institutional. Each group can be guided as many as 3 people with different tasks, namely 1 single guide, while others as hosts, note taker and reviews of each item of problem and solutions offered in the discussion.

Each of these materials can be discussed at each table in a duration of 30 minutes. After each discussion of each material at each table, declared complete by a single guide, the participants will move places at different tables to discuss other material and each person's transfer is random or unstructured.

\subsection{Document Study}

Document study is carried out by researchers by examining a number of written sources both related to the subject matter and the location being studied, so that data can be obtained both primary and secondary.

\subsection{Data Validation}

Assessment of the quality of the results of qualitative research is carried out by determining criteria that are in accordance with research standards (Salman, 2016). This context contains four criteria for data assessment in qualitative research used in this study, namely credibility, transferability, dependability, and confirmability. The four assessment criteria are described as follows:

\subsubsection{Data Credibility}

In this study internal validation was carried out through matching the findings of the study with the results of interviews with informants in three stages of research activities, as follows: (1) the investment of long time togetherness at the research location; carry out continuous observations of crucial facts; the use of triangulation, and elaboration of theories for the interpretation of phenomena that occurred during the research, (2) facilitating peer consultations with community leaders or scientists who knew the research area directly, so this helped researchers to remain 'objective' and discuss assumptions' authentic 'that appeared during the study, (3) confirm the participants to the data, categories, interpretations and conclusions that were tested together with the informants involved since the beginning of this research.

3.4.2 Transferability, describe in detail and in depth of the Socio-Cultural background of community life, through analysis and provision of sufficient information so as to reflect the characteristics of the community under study.

3.4.3 Dependability, involve the auditor in examining the existence of the topics studied at the selected location while also checking the data and information material (audit trial) collected by the researchers while maintaining the consistency of the results of the research with the conclusions formulated.

3.4.4 Data Confirmability, carried out through the reflection of researchers' critical thinking by elaborating the basic assumptions of economic sociology in the perspective of social networks throughout the study of the phenomena that occur, with the aim of achieving trust on the results of research conducted. This data confirmation activity is carried out from the beginning of data collection until the writing process takes place. 


\subsection{Data Analysis}

The main analysis used in this research is analytical qualitative data analysis through interpretation and comprehension. In order to obtain accurate data, field notes are refined, coded data and problems. Coding of data based on the results of criticism made, the appropriate data separated by certain code. The data obtained were analyzed by three stages:

The first stage is the process of rough data reduction of field notes. In the process, selected data are relevant to the research focus. Data reduction is done by creating data summaries, scattering themes, and creating a basic data presentation template.

The second stage is the presentation of data, namely the preparation of a collection of information into a statement for subsequent withdrawal of conclusions. The data are presented in the form of narrative texts, initially scattered and separated on various sources of information, then classified according to theme and analysis needs. At this stage the data are presented in the unity of the theme of the general state of the fishermen community, the description of fishermen activities, the dynamics of the phenomenon of conflict between fishermen, the description of things that are still maintained as a tradition in the management of fisheries resources, and an in-depth description of the role of local institutions in handling or mediating the settlement of fishermen conflict.

Third stage, drawing conclusions based on reduction and presentation of data. The gradual conclusion draws from the general conclusion at the time of data reduction then becomes more specific at the actual conclusion step. This series of processes indicates that the qualitative data analysis in this study combines the data reduction, data presentation, concluding and recurring conclusions.

\section{Discussion}

\subsection{The Dynamic Implementation of Resources Management Community-Based}

The dynamics derived from the word dynamics (Greek) means strength. In the context of society, dynamics means the behaviour of one citizen directly affects other citizens on a reciprocal basis. Understanding of social change was also put forward by Gillin and Gillin. Both of these scholars say that social change as a variation of accepted ways of life, either because of changes in geographical conditions, material culture, population composition, ideology or because of diffusion or new discoveries in society (Soekanto, 2002).

Community-based coastal resource management is a resource management system in which local people are actively involved in the natural resource management processes contained within them, so that the coastal communities manage their resources together and generate a distinctive social interaction. Analyzing the dynamics of community-based coastal resource management, the explanation begins with the next social system how the dynamics in relation to the passage of time in accordance with the substance of its management (Elmer M. Ferrer and Cristi Marie C. Nozawa, 2016; Siti Arista, 2010).

\subsubsection{Social System of Society}

Humans as social beings are part of the universe as well as creatures of God. To maintain its survival according to Arifin (1996) human form three forms of relationship that is the relationship of society with the creator, community relationships with natural resources, and the relationship between communities themselves. The three patterns of relationships that color the journey of resource management relationships in the coastal areas in the social space of society.

From the results of field observations, it is known that the social system of coastal communities of Wabula from sub ethnic Cia-cia. Traditional values are legacy of the predecessors associated with these three aspects.

\subsubsection{The Relationship of Society with the Creator}

Public relations with the creator in the social system related to coastal resource management in Wabula Village. It has a direct and indirect pattern, both individually and collectively. Public relation with the creator has a meaning-laden value that essentially begs protection and fortune to the creator.

In the context of direct human relationship with the creator of Wabula society is established through collective prayer after performing the Friday prayers at the Mosque. This routine prayer ritual is regularly led by Imam in the hope of marine safety in order to capture many catches, including in the hope of successful harvest on the land.

One of the main factors of Wabula society with the creator is the existence of Parabela customary institution which have own structure, duties and responsibilities. In Parabela associated with religion is led by priests, 
khatib, and moji. These three religious leaders were elected and appointed by the community based on deliberations with Parabela and village head.

\subsubsection{Community Relationship with Natural Resources}

In the context of public relations with the universe that took place in Wabula is done through a tender system that is done every open ombo. In addition to this, there is also exploitation by using equipment that is not environmentally friendly by fishermen from outside, such as by Bajo fishermen.

In the context of a harmonious relationship with the universe Wabula's people guard it through activities: Kaombo (a commodity-based protection area). Tunuana dupha ceremony (ritual ceremony at sea) and batata (prayer of safety while trying). The activity has been long and hereditary since a long time as part of the cultural system that is believed to be preserved because it is a mandate from the ancestors. In addition there is a so-called Marine Protected Area created by Coremap II 2006 program and is maintained until now overseen by the Buton Fisheries Department. Although the program is over, the Wabula people are still asking the government to facilitate the existence of Coremap program.

\subsubsection{The Relationship between Communities}

Social interaction is a major form of social process, namely the mutual influence between various areas of community life. According to Soekamto (2001) social interaction is a visible form when people hold each other, either individually or in groups. The forms of social interaction can be in the form of cooperation, competition, conflict or dispute and accommodation.

\subsection{The Period Implementation of Basic Principles of Coastal Resource Management of People-Based}

The dynamics of community-based coastal resource management, the management context is inseparable from the movement of community's continuous (dynamic) that leads to changes in the governance of coastal resources. Therefore history in the coastal resource management system is a construction that can explain the process of the ongoing dynamics itself. It is similarly stated by Masyhuri (1996), that the present approach must be understood by the underlying dynamics, and it is not obtained without doing the study or at least revealing the history of the past.

\subsubsection{Dynamics of Management Resources Based-Tradition}

The government system of the heritage of the sultanate of Buton has given its own color in managing its coastal resources and still feels to this day. The influence of the system changes with the passage of time, including by the entry of government system, economic system and social system.

4.2.1.1 In the First Period around the Year 1332-1960 or the Period of Empire and Sultanate Begins with the History of the Government of the Kingdom of Buton

In the kadie area, the government governed by parabela on the order of the king because it has not been converted to Islam at that time so there is certainly no priest who accompanies parabela in managing coastal resources. Along with the development of the time of the government system of the kingdom of Buton was transformed into a sultanate which occurred in $1542 \mathrm{AD}(948 \mathrm{H})$, simultaneously with the inauguration of Lakilaponto as the first sultan of Buton, with the title of Sultan Kaimuddin Khalifatul Khamis. After King Lakilaponto converted to Islam, the kingdom of Buton grew and reached its heyday in the 17th century. The royal ties with the Islamic religion are very close, especially with the Sufi elements. The royal law of Buton is called Martabat Tujuh, a very popular theme in Sufism in it governing the utilization and management of resources as God's creatures. And it was at this time that the parabela government system was accompanied by Imam managing coastal resources in the kadie region.

\subsubsection{The Second Period or the Decline Period (1970-1990)}

In the early 1970s in Wabula, Takimpo and Halimombo the implementation of kaombo covered limited areas and types of resources, then began to gradually expand as the seabed needs and increased demand for marine products and increased activity in the region by both local fishermen and outside fishermen. While the old kaombo still depends on the needs of the community that is for the needs of the customary party pidoanokuri, so in a matter of months, kaombo still ranged between 6 to 12 months.

\subsubsection{The Third Period or Period of Resurrection (1991 until Now)}

The next development, after about 20 years oscillated from 1970 to 1990, around 1991 the customary institutions that had been "empty" in some areas of Buton, including Takimpo and Wabula, Bahari Village and others then rose and live again. This situation is in line with the development of sustainable development due to the fact that 
the limited resources of natural resources, both due to environmental damage, population growth, technological developments and others. This is different from several other villages including: Wawoangi Village and Boneatiro Village which until now has not been able to revive the institutional custom. Although during field interviews with some of the village community leaders, they missed the presence of sarano adati while they were reconstructed. The longing for community life that is full of customs that make peaceful is the main reason for the life and resurgence of sarano adati in several locations.

\subsubsection{Determine Factors against Ecosystem Resource Management Based on Tradition and Program}

Strategic measures as a community-based coastal resource management effort combine traditional management-based systems with modern-based management systems that took place in Wabula 2005 and continue to date.

\section{Coastal Resource Management Mechanism Combining Kaombo and DPL System}

Comparison of Kaombo System Resource Management with DPL

\begin{tabular}{|c|c|c|c|}
\hline No. & Description & Kaombo & DPL \\
\hline 1. & Purpose & $\begin{array}{l}\text { 1. Protect the tradition } \\
\text { 2. Conservation of commodities }\end{array}$ & $\begin{array}{l}\text { 1. Conservation area } \\
\text { 2. Source of village income }\end{array}$ \\
\hline 2. & Norms & $\begin{array}{l}\text { 1. Do not take the type: sea cucumber, lola, lobster, seven } \\
\text { eyes, octopus and japing-japing } \\
\text { 2. It is prohibited to undermine and conduct untruthful } \\
\text { activities in the Kaombo region } \\
\text { 3. Taking other types using environmentally friendly fishing } \\
\text { gear } \\
\text { 4. The prohibited area covers the administrative area of the } \\
\text { village }\end{array}$ & $\begin{array}{l}\text { Prohibited from taking all types of } \\
\text { organisms in DPL }\end{array}$ \\
\hline 3. & $\begin{array}{l}\text { Base } \\
\text { protection }\end{array}$ & $\begin{array}{l}\text { Comodities-Based (lola, sea cucumber, japing-japing, seven } \\
\text { eye) }\end{array}$ & $\begin{array}{l}\text { Area-based } \\
\text { Ecosystem }\end{array}$ \\
\hline 4. & Wide area & $\begin{array}{l}\text { The width of the highest tide limit to the sea depth of } 20 \mathrm{~m} \text { is } \\
\text { where the cluster of corals (pasi) as a breeding ground for } \\
\text { important economical marine biota }\end{array}$ & $\begin{array}{l}\text { Narrow } \\
\text { (Area: at Wabula }=1.5 \text { ha) }\end{array}$ \\
\hline 5. & $\begin{array}{l}\text { Time of } \\
\text { protection }\end{array}$ & Temporary & Permanent \\
\hline 6. & Basic protection & $\begin{array}{l}\text { 1. Biota given the opportunity to breed } \\
\text { 2. For optimal economic results } \\
\text { 3. The obligation to protect as a consequence of ownership } \\
\text { rights }\end{array}$ & $\begin{array}{l}\text { 1. Biota is given a chance to breed } \\
\text { 2. The obligation to protect as a } \\
\text { consequence of property rights }\end{array}$ \\
\hline 7. & Boundary mark & There is but not clear & There is a DPL buoy buffer flag \\
\hline 8. & Surveillance & Sea guard and Wabula fishermen & Reef Watcher-COREMAP \\
\hline 9. & Basic law & Orally & Written in village regulation \\
\hline 10. & Implementation & Village government with Parabela & LPSTK \\
\hline
\end{tabular}

Source: Primary Data Processing Results, 2017

\subsection{The Implementation of Basic Principles of Resource Management People-Based}

\subsubsection{Mobilization and Community Participation}

Public participation in the process of gathering information, consultation, decision making, initiation of action and evaluation so as to increase knowledge and involvement in PSPBM efforts in its territory. Public participation strengthens the local population and raises the level of knowledge (Gruber, 2010). 
The principle of community in participation and mobilization has a fairly high application in Takimpo and high in Wabula. High community participation in managing the coastal resources of Wabula is due to the collaboration between sarano adati with LPSTK so that indigenous people are more aware of understanding that has been given by the program supported by guarantees with the message from Parabela to participate. With the COREMAP II program of the government in which the guarding of the sea from damage as a base, the principle is the same as that believed and carried out by the community through the institutional customs of Parabela.

\subsubsection{Social Capital and Partnership}

The principle of social capital and partnership of the PSPBM system has a low application in Takimpo and quite high in Wabula. The fundamental difference between the two systems, namely in the areas where PSPBM programs exist, there are various activities undertaken to improve the capacity of communities to manage their resources. While in a purely tradition-based area, involvement in managing coastal resources is more due to customary orders that have been ongoing for generations and are less likely to flourish.

\subsubsection{Resources and Justice}

The application of the principle of resources and justice to the PSPBM system of traditional-Based in Takimpo is quite high and Wabula is high. The existence of sarano adati to the people of Takimpo and Wabula is very important in strengthening the social relations of indigenous people and executor of ritual procession in maintaining the harmony of communication relationships with coastal nature, resulting in the utilization of resources with due observance of the principles of justice and sustainability.

\subsubsection{Dissemination of Information and Communication}

Implementation of principle information capital and communication in PSPBM traditional-based system in Takimpo is low while in Wabula high enough. Various meetings, trainings, workshops, seminars and others have been conducted by program managers at both the PMU (district), RCU (provincial) and NCU (center) levels. In addition to the design in the form of the meeting, there is the dissemination of information in written form, namely brochures, banners, billboards and others. Efforts made by the program was effective in the process of disseminating information and communication to the community about coastal resource management efforts.

\subsubsection{Research and Development of Information}

The need for a general information supported by accessibility to all components is generated by a number of researchers. This information is based on the integration of information including technical and scientific as well as social, quality of life and other forms of indigenous local knowledge. So the decision should be based on a comprehensive and systematic information that includes local knowledge, an understanding of ecosystems, and an economic evaluation of environmental assets (Gruber, 2010).

Implementation of social capital principle and partnership on PSPBM Traditional-Based system in Takimpo did not go well. While in Wabula its application is low.

\subsubsection{Empowerment and Delegation of Authority}

The application of the principle of empowerment and delegation of authority is high in Takimpo and Wabula. The authority of indigenous peoples Takimpo and Wabula under Parabela in managing coastal resources since the reign of the sultanate until now is still acknowledged even though it was lost but came back to life. The authority possessed is useful in strengthening the unity of indigenous peoples that are generally lacking in the community with the management of resources and program approach.

\subsubsection{Legitimacy and Public Trust}

For effective and sustainable PSPBM, the work of an organization should be viewed by the community as a legitimacy in building trust and credibility supported by local officials (Gruber, 2010).

Takimpo and Wabula village have the application of the principle of legitimacy and high public trust. Great tasks and responsibilities owned by Parabela balanced with the authority it has turned out to be well utilized among others in managing coastal resources. The effort is believed to be a means of devotion to society and a form of constancy to God who makes Parabela is often referred to as a saint. LPSTK leaders who are actually community leaders who were selected at the beginning of the existence of the program turned out to lack legitimacy and public confidence. This causes weak support and loyalty of the community to engage directly or indirectly in the management of coastal resources in the region.

4.3.8 Feedback, Monitoring and Accountability

Implementation of the feedback, monitoring and accountability principles of the PSPBM system of 
traditional-based in village in Takimpo is low, while in Wabula the application of the feedback principle is quite high. The existence of Coremap II as a program equipped with instruments to monitor progress as well as improve management capacity so that the monitoring and evaluation system is done. This system, which generally takes place in writing, is supported by unskilled technologies and skilled human resources in traditional-based PSPBM.

\subsubsection{Adaptive Leadership}

The application of adaptive leadership principles is the traditional-based PSPBM system in Takimpo is quite high, and Wabula is high. The ability of Parabela to organize its people in managing the natural resources that have been going on for a long time and still exist today is one of the main considerations in achieving this principle. Parabela's ability to resolve conflicts over the utilization of coastal resources reached to them, strengthened by the support of the village government and the security apparatus, and the existence of the kaombo region, which has been established and known and acknowledged de facto by the fishermen and communities both within and outside Takimpo and Wabula. However, the recognition of the boundaries and the rules of its management in writing about the area in the ombo is not there, this means that the potential mutual claims of authority, especially with neighboring villages or adjacent to it.

\subsubsection{Participatory Decision Making}

The principle of participatory decision-making on the traditional-based PSPBM system in Takimpo has a fairly high implementation, while the traditional and project-based PSPBM system at Wabula. The fundamental difference in the decision-making process is that traditional leader in addition to having an executive and legislative role as well as a judicial. The decision-making authority, among other things, resolves conflict issues arising from the use of unfriendly fishing gear. This is different from the LPSTK which is only entitled to report the problem to the authorities.

\subsection{Comparison of Application Level of Enabling Environment Principles: Optimal Preconditions or Early Conditions}

Principles of early efforts to anticipate environmental problems in the traditional-based PSPBM system in Takimpo has a fairly high application, while in Wabula is high. In all the study areas have relatively homogeneous community structures, so the potential for conflict is less. Another disadvantage is that safeguards against tradition-based systems are not assertive because they are not permanent, nor are commodities subject to change. The existence of commodity-based protection led to other commodities being freely arrested. This can potentially occur excessive exploitation of course affects other commodities as a single entity in the ecosystem. This conservation effort is different from that done using the program approach. Marine Protected Areas as an area, so that protection efforts are done on a single ecosystem unity.

\subsubsection{Cooperation and Conflict Resolution}

Principles of cooperation and conflict resolution in regions with tradition-based PSPBM systems have moderate application, mixed-based systems (program and tradition) have high application. While in areas with program-based PSPBM systems have less application on the principle. Homogeneous social reality and the absence of conflicts in the use of the region make the minus conflicting factor in managing coastal resources in areas that still have tradition in managing their resources. While the resources managed through the program, capacity building planning and resource management strategies at Wabula are strategic and preventive measures for handling in case of conflict in coastal resource management.

\subsubsection{Loyalty, Commitment to Custom Values, and Public Trust}

From the results of processing and data analysis it is known that there is no application on the project-based PSPBM system. The traditional PSPBM system in Takimpo and Wabula has adopted loyalty principles, commitment to custom values, and community trust.

The high commitment of customary leaders (parabela) is supported by the loyalty of Takimpo and Wabula society that wrapped with strong value system together in the community making high principle application in both areas. This is similar to the research conducted by Darman (2007), that customary rituals that are often held in indigenous communities of Karampuang are full of symbols and meanings so that the meaning of various cultural and religious symbols in turn gives birth to loyalty and noble bond.

\section{Conclusion}

The dynamics of the implementation of community-based coastal resource management is constructed by the socio-cultural order which continues to develop in every time. While the creation of the program-based 
management system, the dynamics based on the level of needs and sustainability of ecosystems established by the Ministry of Fisheries are included in the Core map program. The application of the basic principles of community-based coastal resource management is very dynamic and manifested on a local conceptual basis. A key factor influencing the existence of a community-based coastal resource management system lies in the weakness of the authority given to the community, and vice versa, in the program is community support in managing coastal resources in its territory. The adaptive / accommodative coastal resource management scenario refers to the capacity of the community supported by the access and control it has in managing the coastal resources in its territory. The combination of Community-Program management and the Program mutually contributes to the sustainability of coastal resources with increasing coastal area, namely Ombo and Marine Protected Areas.

\section{References}

Adams, A., \& Cox, A. L. (2008). Questionnaires, in-depth interviews and focus groups. In Cairns, P., \& Cox, A. L. (Eds.), Research Methods for Human Computer Interaction (pp. 17-34). Cambridge, UK: Cambridge University Press. https://doi.org/10.1017/CBO9780511814570.003

Alfgeir, L. K., Jon, S., Inga, D. S., \& John, P. A. (2017). Data Collection Procedures for School-Based Surveys Among Adolescents: The Youth in Europe Study. Journal of School Health, 83(9), 662-667.

Allmark, P. J., Boote, J., Chambers, E., Clarke, A., Mcdonnell, A., Thompson, A., \& Tod, A. (2009). Ethical issues in the use of in-depth interviews: Literature review and discussion. Research Ethics Review, 5(2), 48-54. https://doi.org/10.1177/174701610900500203

Arief, A. A. (2007). Artikulasi Modernisasi dan Dinamika Formasi Sosial pada Nelayan Kepulauan di Sulawesi Selatan, UNHAS, Makasar.

Arieta, S. (2010). Community Based Tourism Pada Masyarakat Pesisir; dampaknya Terhadap Lingkungan dan Pemberdayaan Ekonomi Jurnal Dinamika Maritim, 2(1), 71-79.

Babbie, E. (2003). The Practice of Social Research (10th ed.). Belmont, CA: Wadsworth publishing.

Boateng, I. (2018). Policy Process in Coastal and Marine Resource Management in Ghana. Department of Geography, University of Portsmouth Buckingham Building.

Bonifacio, F. M. (1993). Perspective and Experiences in Community-Based Resource Management. Understanding Community-Based Resource Management Environment and Resource Management Project (ERMP). Philippines.

Boyce, C., \& Neale, P. (2006). Conducting In-Depth Interview: A Guide for Designing and Conducting In-Depth Interviews for Evaluation Input. Pathfinder International.

California Environmental Association (CEA). (2018). Trends in Marine Resources and Fisheries Management in Indonesia.

Creswell, J. (2008). Research Design: Qualitative, Quantitative, and Mixed Methods Approaches (3rd ed.). Thousand Oaks, CA: Sage publications.

Crossman, A. (2017). How to Conduct a Research Interview: A Brief Introduction to the Research Method. Thought Co. Retrieved from https://www.thoughtco.com/in-depth-interview-3026535

Dagmar, H., Xavier, M. R., Ferenc, M., \& Joszef, R. (Eds.). (2008). Development of a Data Collection Protocol for Specialist Harm Reduction Agencies Foundation Regenboog AMOC.

Dana Lynn Driscoll. (2017). Introduction to Primary Research: Observations, Surveys, and Interviews. Print versions of the volume are available for purchase directly from Parlor Press and through other booksellers.

Elmer, M. F., \& Cristi, M. C. N. (2016). Community-Based Coastal Resources Management In The Philippines: Key Concepts, Methods And Lessons Learned. University of the Philippines at Diliman.

Gleason, M. (2018). Ocean \& Coastal Management. The Nature Conservancy California Coastal and Marine Program, Monterey, California, USA

Gruber, J. S. (2010). Key Principles of Community-Based Natural Resource Management A Synthesis and Interpretations of Identified Effective Approaches for Managing the Common. Enviromental Management (2010) 45 pp 52-68. https://doi.org/10.1007/s00267-008-9235-y

Harvey, L. (2012-2017). Researching the Real World. Retrieved from https://qualityresearchinternational.com/methodology 
Husain. (2012). Peran Kepemimpinan Parabela Dalam Menjaga Hutan Kaombo di Buton. Disertasi.

Key, R., \& Alder, J. (1999). Coastal Planning and Management. E \& FN Spon, an imprint of Routlegde, London.

Kusnadi. (2002). Konflik Sosial Nelayan, Kemiskinan dan Perekrutan Sumberdaya Perikanan. LKYS Jogyakarta. Yogyakarta.

Kvale, S. (1996). Interviews: An Introduction to Qualitative Research Interviewing. Thousand Oaks, CA: Sage.

Lampe, M. (2000). Dimensi Sosial Budaya Pesisir Ditinjau dari Pendekatan Sejarah Antropologi Maritim. Kasus Teluk Bone. UNHAS, Makassar.

Legard, R., Keegan, J., \& Ward, K. (2003). In-depth interviews. In Richie, J., \& Lewis, J. (Eds.), Qualitative Research Practice (pp. 139-168). Sage, London.

Matulada. (1997). Kebudayaan Bugis-Makassar. Penerbit, Jambatan. Jakarta.

Nalefo, L. et al. (2013). Towards an Institutional Sustainable Agriculture in Parabela. World Applied Sciences Journal, 26(Natural Resources Research and Development in Sulawesi Indonesia), 55-59.

Nikijuluw. (2002). Rezim Pengelolaan Sumberdaya Perikanan. Pustaka, Cidesindo, Jakarta.

Ohama, Y. (2001). Conceptual Framework of Participatory Local Social Development, Nagoya: JICA.

Pomeroy, R. S. (1995). Community-Based and Co-Management Institutions for Sustainable Coastal Fisheries Management in Southeast Asia, Philippines.

Rashidpour, L. (2010). The Pattern of Local Community-Based Management for sustainable Rural Development in West Azerbaijan Province. American Journal of Agricultural and Biological Sciences, 5(1), 84-88.

Rasyidi, M. (2008). Studi Nilai Budaya Pada Lembaga Adat Suku Sasak Sebagai Kekuatan Dalam Mebangun Nilai Luhur Budaya Bangsa. Agroteksos, 18(1-3).

Salman, D. (2011). Kelembagaan Pembangunan Pertanian. Bahan Kuliah Program Doktor Ilmu-Ilmu Pertanian, Program Pascasarjana UNHALU. Kendari: Tidak Dipublikasikan.

Salman, D. (2012). Tarian Paradigma Dalam Pendidikan Sosiologi dan Penyuluhan Pertanian Masa Depan. Makalah yang disampaikan dalam Pertemuan Nasional Pendidikan Sosiologi dan Penyuluh Pertanian Indonesia. Bandung.

Stephanie, Z. et al. (2000). Data Collection Instrument and Procedure for Systematic Reviews in the Guide to Community Preventive Services. American Journal of Preventive Medicine, 18(1), 44-47. https://doi.org/10.1016/S0749-3797(99)00122-1

Suradisastra, K. (2011). Revitalisasi Kelembagaan untuk Mempercepat Pembangunan Sektor Pertanian dalam Era Otonomi Daerah. Jurnal Pengembangan Inovasi Pertanian, 4(2), 118-136.

Tulungen, J. J., Kasmidi, M., Rotinsulu, C., Ompudus, M., \& Tangkilisan, N. (2004). Panduan Pengelolaan Sumberdaya Pesisir Berbasis Masyarakat. USAID-Indonesia. Coastal Resource Management Project 1997-2003.

Ubyarto, dkk. (2000). Nelayan dan Kemiskinan. Studi Ekonomi Antropologi di Dua Desa Pantai. Rajawali, Jakarta.

Uphoff, N. (1986). Local Institutional Development: An Analytical Sourcebook with Cases. Kumarian Press, New York.

Uphoff, N. (1992). Local Institution and Participation for Sustainable Development. IIED. London.

\section{Copyrights}

Copyright for this article is retained by the author(s), with first publication rights granted to the journal.

This is an open-access article distributed under the terms and conditions of the Creative Commons Attribution license (http://creativecommons.org/licenses/by/4.0/). 